\title{
The Pathogenicity of Sclerotium rolfsii on Cyperus difformis and its Potential Host Specificity among the Genus Cyperus
}

\section{Wei Tang ${ }^{1,2}$, Jing Kuang ${ }^{1}$ and Sheng Qiang ${ }^{1 *}$}

${ }^{1}$ Weed Research Laboratory, Nanjing Agricultural University, Nanjing, Jiangsu 210095, P. R. China

${ }^{2}$ Zhejiang Branch of National Pesticide R\&D South Center, Zhejiang Chemical Industry Research Institute, Hangzhou 310023, China

\begin{abstract}
Sclerotium rolfsii Sacc. infects more than 500 species of monocotyledonous and dicotyledonous plants except Cyperaceae family. The pathogenicity of a $S$. rolfsii isolate was evaluated by seven Cyperus species in order to explicate host specificity to Cyperaceae family. The results showed that only C. dofformis L. was infected with typical water-soaked lesions of the basal stem, which progressed to rotting, wilting, blighting, and eventually death. The performance of hyphae on the surface of Cyperus plants was compared and found that only stomata of $C$. difformis were adhered by hyphae of $S$. rolfsii. The infection process of $S$. rolfsii on leaf sheath of stem base in $C$. difformis showed that dense mycelial networks and ramifying hyphae were usually formed on the inoculated tissues, then growing hyphal tips were observed to spread wavelike on the stem surface, reaching the stomata between the leaf veins accurately and directly enter the host through stomata. Differences of the main micro-morphology characters of leaf sheath abaxial epidermis among the seven species were compared. The stomata of $C$. difformis were always presented between the leaf veins ( 3 or 4 rows of cells from the leaf veins), while the stomata of tolerant Cyperus species were close to the leaf veins. Underneath the stromata of $C$. difformis were air chambers, however vascular bundles were always present underneath the stomata of the tolerant Cyperus. Our study indicates that different anatomical structures in genus Cyperus may be associated with resistance to $S$. rolfsii infection.
\end{abstract}

Keywords: Sclerotium rolfsii isolate SC64; Cyperus difformis; Stromata; Transverse section; Host specificity; Infection process

\section{Introduction}

Sclerotium rolfsii is a versatile soil borne pathogen commonly occurs in the tropics, subtropics, and other warm regions, especially at high humidity and warm temperatures. It may cause a variety of diseases, for example, damping off of seedlings, collar or stem rot, foot rot, crown rot, Sclerotium wilt and blight [1]. Previous studies have reported that $S$. roflsii infects more than 500 species of monocotyledonous and dicotylednous plants, especially severe on vegetables, flowers, legumes, cereals, forage plants and weeds [2,3]. The signs and symptoms of Sclerotinia minor were observed on yellow nutsedge (Cyperus esculentus L.) in Bertie County [4], but infection of S. rolfsii in Cyperus spp. has not been reported yet.

The histopathology of infection by Sclerotium spp. has been studied in considerable detail. Previous histopathological studies have reported that $S$. rolfsii penetrates host tissue by formation of appressoria $[5,6]$, followed by apparent tissue necrosis in advance of the mycelium [6]. Phytotoxins such as oxalic acid and cell wall degrading enzymes play a key role in the infection of a host [1,7] and a multi-enzyme system for the degradation of different polysaccharides was discovered in the host tissue [8]. Although "hyphal aggregates" have been reported to form during infection by $S$. rolfsii, the role of these aggregates in pathogenesis has not been determined, and tissue death in advance of mycelial growth has also not been conclusively demonstrated.

S. rolfsii isolate SC64, a fungus indigenous in Jiangsu province, was isolated from an alien invasive weed Solidago canadensis L. (Canadian goldenrod, Asteraceae) [9]. The fungus caused basal stem rot lesions on S. canadensis and was found capable of controlling some dicotyledon weeds and Cyperus difformis, which was unrecognized as the host before, in a host range test and field trials [10]. Understanding the infection differences between $C$. difformis and other species of the Cyperus family to S. rolfsii isolate SC64 is imperative to estimating the host range of this isolate as a biocontrol agent and enriching the infection mechanism of $S$. rolfsii.
Therefore, the objectives of this research were to 1) determine the host specificity of $S$. rolfsii isolate SC64 among 7 species in genus Cyperus 2) study in detail the performance of S. rolfsii isolate SC64 on $C$. difformis stem surface by using light and scanning electron microscopy and 3) compare the transverse section of $C$. difformis with six other Cyperus species by using paraffin section observation and try to elucidate the selective mechanism of $S$. rolfsii among Cyperus spp. based on anatomical structure differences.

\section{Materials and Methods}

Pathogen and host plant: Isolate SC64 of S. rolfsii from S. canadensis in Nanjing city, Jiangsu province of China, was used throughout this study. For inoculum preparation, the fungus was grown in Petri dishes on potato dextrose agar (PDA) at $28^{\circ} \mathrm{C}$ in the dark for 2-3 days.

Greenhouse-grown host plants included in this study were $C$. difformis L.; C. rotundus L.; C. iria Linn.; C. glomeratus L.; C. amuricus Maxim. and C. cuspidatus H.B.K. Plants were transplanted from wild field (near a lake in Xiamafang Park, Nanjing city) into plastic pots (14 cm in diameter) and grown in the greenhouse under natural photoperiod and temperature conditions.

Host specificity tests: A starter culture of isolate SC64 was produced by placing five agar plugs ( $5 \mathrm{~mm}$ diameter), cutting from the actively growing margin of the PDA culture, into $100 \mathrm{ml}$ ( $250 \mathrm{ml}$ flask) potato dextrose broth (PDB, potato extract, $20 \mathrm{~g}$ D-glucose and water to

*Corresponding authors: Qiang S, Weed Research Laboratory, Nanjing Agricultural University, Nanjing, Jiangsu 210095, P. R. China, Tel: 8625 84395117; Fax: 8625 84385117; E-mail: mailto:wrl@njau.edu.cn

Received April 28, 2015; Accepted June 15, 2015; Published June 25, 2015

Citation: Tang W, Kuang J, Qiang S (2015) The Pathogenicity of Sclerotium rolfsi on Cyperus difformis and its Potential Host Specificity among the Genus Cyperus. J Plant Pathol Microbiol S3: 002. doi:10.4172/2157-7471.S3-002

Copyright: (C) 2015 Tang W, et al. This is an open-access article distributed under the terms of the Creative Commons Attribution License, which permits unrestricted use, distribution, and reproduction in any medium, provided the original author and source are credited. 
Citation: Tang W, Kuang J, Qiang S (2015) The Pathogenicity of Sclerotium rolfsii on Cyperus difformis and its Potential Host Specificity among the Genus Cyperus. J Plant Pathol Microbiol S3: 002. doi:10.4172/2157-7471.S3-002

Page 2 of 6 shaking incubator $(110 \mathrm{rpm})$ for $7 \mathrm{~d}$. and aseptically blended. The starter culture was then used to inoculate plants growing in pots. Each pot contained three plants and each species was replicated four times. The experiments were performed twice. Each plant was inoculated with $0.5 \mathrm{ml}$ of starter culture to the basal stem by $1 \mathrm{ml}$ pipettor. After inoculation, plants were moved to greenhouse with natural light and temperature of $25 \sim 35^{\circ} \mathrm{C}$. The soil was maintained wet throughout the experiment by adding water to saucer under the pots. Control plants were inoculated with autoclaved water only. Plants were monitored every day for two weeks to detect the characteristic symptoms of basal stem water soaked lesions and wilt caused by $S$. rolfsii. Monitoring was conducted to record the presence or absence of these symptoms.

A dose response test of $C$. difformis to $S$. rolfsii SC64 was also carried out. Seedlings with 3.5 5.5 leaf stages were inoculated with fresh fungus-infested cotton seed hulls at $60 \sim 120 \mathrm{~g} \cdot \mathrm{m}^{-2}$. Plant mortality and fresh weight reduction were evaluated 14 days after inoculation. Surviving plants were excised at soil surface level, weighed and the percentage of biomass reduction was determined as compared to the control plants. The experiment included four replications for each treatment and was repeated once. The control treatment was treated with autoclaved cotton seed hulls.

Inoculation of stems of Cyperus: Mature Cyperus plants stem were excised at the soil surface level, rinsed in tap water and blotted dry. Leaves were peeled off carefully from the stems and placed on moistened filter paper in Petri dishes ( $9 \mathrm{~cm}$ in diameter). Tissues were inoculated with agar disks ( $5 \mathrm{~mm}$ diameter) cut from the advancing margin of 3-day old cultures of the pathogen grown on PDA. Dishes were sealed in polyethylene bags and incubated at $25 \sim 28^{\circ} \mathrm{C}$ with a 12 hr photoperiod under cool-white fluorescent lights.

Light microscopy: At approximately 4-hr time intervals from 12 to 32 $\mathrm{hr}$ after inoculation, pieces of infected tissues from appropriate regions were fixed for $24 \mathrm{hr}$ in FAA (70\% ethanol : $38 \%$ formaldehyde : glacial acetic acid, 90:5:5, v/v/v). The growth of S. rolfsii SC64 was estimated by lactophenol aniline blue staining as describe previously (Govrin and Levine, 2000). The other part of uninoculated stem of the 7 Cyperus species was fixed in FAA for observing the surface morphological characteristics and transverse sections with light microscopy. The transverse sections of stems were made through usual paraffin method in thickness of $8 \mu \mathrm{m}$, and stained with safranine and fast green. The pictures were taken using the image analysis software Motic Images Plus version 2.0

Scanning electron microscopy: Leaf and stem Samples from C. dofformis were taken $8,12,16,20$ and $24 \mathrm{hr}$ after inoculation (hai). Samples were first fixed with $4 \%(\mathrm{v} / \mathrm{v})$ glutaraldehyde in $50 \mathrm{mM}$ same buffer for $3 \mathrm{hr}$. After dehydration in a graded acetone series, the samples were critical-point dried, mounted on stubs, sputter coated with gold-palladium, and viewed using a HITACHI S-3000 scanning electron microscope operating at $15 \mathrm{kV}$. make $1 \mathrm{~L}, \mathrm{pH} 5.0)$. The starter culture was cultured $\left(28^{\circ} \mathrm{C}\right)$ in an orbital phosphate buffer ( $\mathrm{pH}$ 6.8) for $8 \sim 10 \mathrm{hr}$ at $4^{\circ} \mathrm{C}$, then rinsed with the

\section{Results}

Host specificity and pathogenicity to Cyperus difformis: Two days after inoculation of $S$. rolfsii, characteristic lesions were observed on the basal stems $C$. difformis. Leaves collapsed $2 \sim 5$ days after inoculation, and then $2 \sim 4 \mathrm{~cm}$ basal stem rot lesions appeared and the whole plant began to wilt and die. Meanwhile white sclerotia appeared around the basal stem and soil surface and quickly turned brown in 1 2 days (Figure 1). Infested tissues and mature scleotia were collected for re-isolation of the fungus. Microscopic examination and culture of isolate from $C$. difformis confirmed that it had been infected by S. rolfsii SC64. None of other plants inoculated with $S$. rolfsii showed any signs of pathogenicity and therefore are considered to be immune to this pathogen (Table 1). Estimated parameters of fitted logistic equation in dose response test showed that LD50/90 were 79.8/122.7 $\mathrm{g} \cdot \mathrm{m}^{-2}$ and $64.4 / 113.4 \mathrm{~g} \cdot \mathrm{m}^{-2}$ for plant mortality or fresh weight reduction of $C$. difformis when treated with S. rolfsii SC64-infested cotton hulls (Table 2).

Performance of S. rolfsii SC64 hyphae on Cyperus stems by Light microscopy: In order to further understand how the $S$. rolfsii isolate

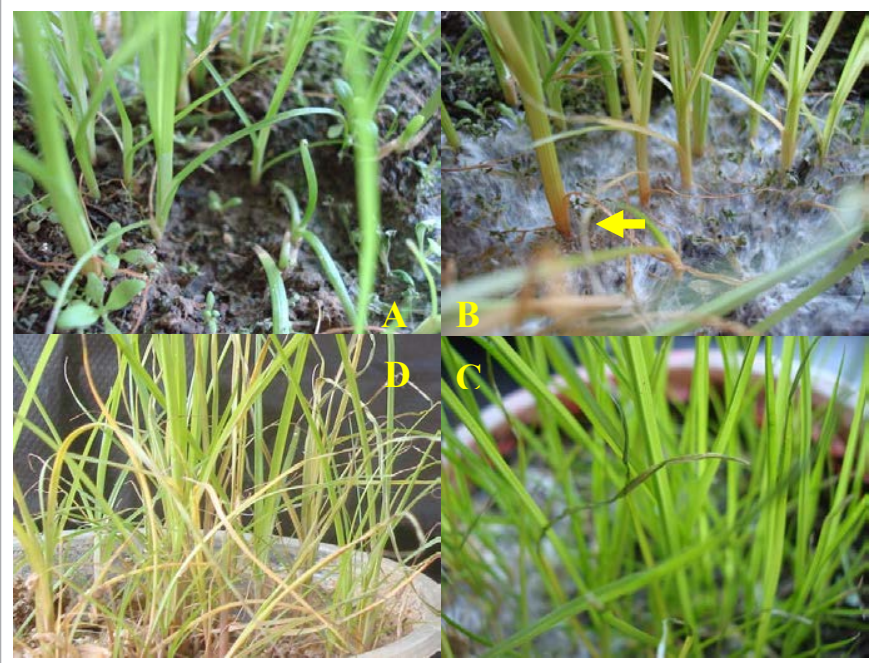

Figure 1: Symptoms of stem rot on Cyperus difformis L. caused by Sclerotium rolfsii isolate SC64. A, Healthy plants; B, Typical symptoms on stems and near the soil line after 2 dai; C, Typical symptoms of leaves wilt after 2 dai; $D$, plant mortality after 10 dai.

\begin{tabular}{|c|c|}
\hline Cyperus Species & Rating for S. rolfsii SC64 \\
\hline C. amuricus Maxim. & - \\
\hline C. cuspidatus H.B.K. & - \\
\hline C. rotundus L. & - \\
\hline C. glomeratus L. & - \\
\hline C. iria L. & - \\
\hline C. compressus L. & + \\
\hline C. difformis L. & \\
\hline
\end{tabular}

Note: "+" means shows infection.

Table 1: Plants included in host-specificity testing of S. rolfsii isolate SC64.

\begin{tabular}{|c|c|c|c|c|c|c|c|c|}
\hline \multirow{2}{*}{ Efficacy $(\%)^{a}$} & \multicolumn{5}{|c|}{ Dosage $\left(g \cdot \mathrm{m}^{-2}\right)$} & \multirow{2}{*}{ Regression equation } & \multirow{2}{*}{$\mathrm{LD}_{50} / \mathrm{g} \cdot \mathrm{m}^{-2}$} & \multirow{2}{*}{$\mathrm{LD}_{90} / \mathrm{g} \cdot \mathrm{m}^{-2}$} \\
\hline & 0 & 60 & 80 & 100 & 120 & & & \\
\hline PM & $0 e$ & $33.3 d$ & $51.7 \mathrm{c}$ & $66.7 \mathrm{~b}$ & $87.7 a$ & $y=44761.1-44761.1 /\left(1+(x / 11540.47)^{\wedge} 1.37\right)\left(R^{2}=0.9958\right)$ & 79.8 & 122.7 \\
\hline FW & $0 \mathrm{e}$ & $42.4 d$ & $71.3 c$ & $85.2 b$ & $91.6 a$ & $y=97.10-97.1 /\left(1+(x / 63.56)^{\wedge} 4.39\right)\left(R^{2}=0.9994\right)$ & 64.4 & 113.4 \\
\hline
\end{tabular}

a MR: Mortality Rate (\%), FW: Fresh Weight Reduction (\%). Means within the same row followed by different letters are significantly different at $P<0.05$ level according to Duncan's multiple-range test.

Table 2: Effect of fungus-infested cotton hulls of S. rolfsii SC64 application dosage on plant mortality and fresh weight reduction of $C$. difformis. 
Citation: Tang W, Kuang J, Qiang S (2015) The Pathogenicity of Sclerotium rolfsii on Cyperus difformis and its Potential Host Specificity among the Genus Cyperus. J Plant Pathol Microbiol S3: 002. doi:10.4172/2157-7471.S3-002

SC64 may differentially infect its hosts, in this work we demonstrated the performance of hyphae on the hosts stem surface. Temporal analysis of the fungal structures upon infection of Cyperus difformis with the $S$. rolfsii isolate SC64 via aniline blue staining indicated that, at $12 \mathrm{hr}$ post inoculation, hyphae of $S$. rolfsii SC64 ramified over the surface of all inoculated tissue (Figure 2a). Hyphae frequently ramified towards the stomata (Figure $2 \mathrm{~b}-2 \mathrm{~d}$ ), where more intense staining was found. Ramified hyphae or adhering upon stomata were not observed on the non-susceptible Cyperus species (Figure 2e and 2f).

The infection process on C. difformis stem surface by S. rolfsii SC64: The scanning electron microscopy (SEM) observations showed that the running hyphae grew from the inoculum disks over the stem surface and formed a dense hyphal network, especially between the leaf veins (Figure 3a) within 12 hai. The host surface was covered by the ramifying hyphae, which were relatively smaller (Figure 3b). Growing hyphal tips on the root surface were also observed to spread wavelike on the stem surface, reaching the stomata between the leaf veins accurately (Figure $3 \mathrm{c}$ and $3 \mathrm{~d}$ ). Slime material (mucilage) covering hyphae, hyphal tips and extending between the hyphae, was also deposited on the plant surface. Small changes in cuticle integrity were observed (Figure3f) and the infection hyphae entered host tissue through the open stomatal (Figure $3 e)$. Appressorium structure was also observed on the stomata. Water soaked lesions were visible in the leaf and stem parts which underneath the inoculum disks and the host tissue turned soft at this developmental stage. Hyphae also penetrated the host surface directly through cracks. The host surface was depressed and penetrating hyphae grew into the host tissue (Figure $4 \mathrm{~g}$ and $4 \mathrm{~h}$ ).

The comparison of the main micro-morphology characters of basal leaf abaxial epidermis among 7 species of Cyperus: The basal stem leaf abaxial epidermis structures of 7 species of the genus Cyperus were studied under light microscope. The results (Table 3) showed that the genus Cyperus was highly consistent in the micro-morphology

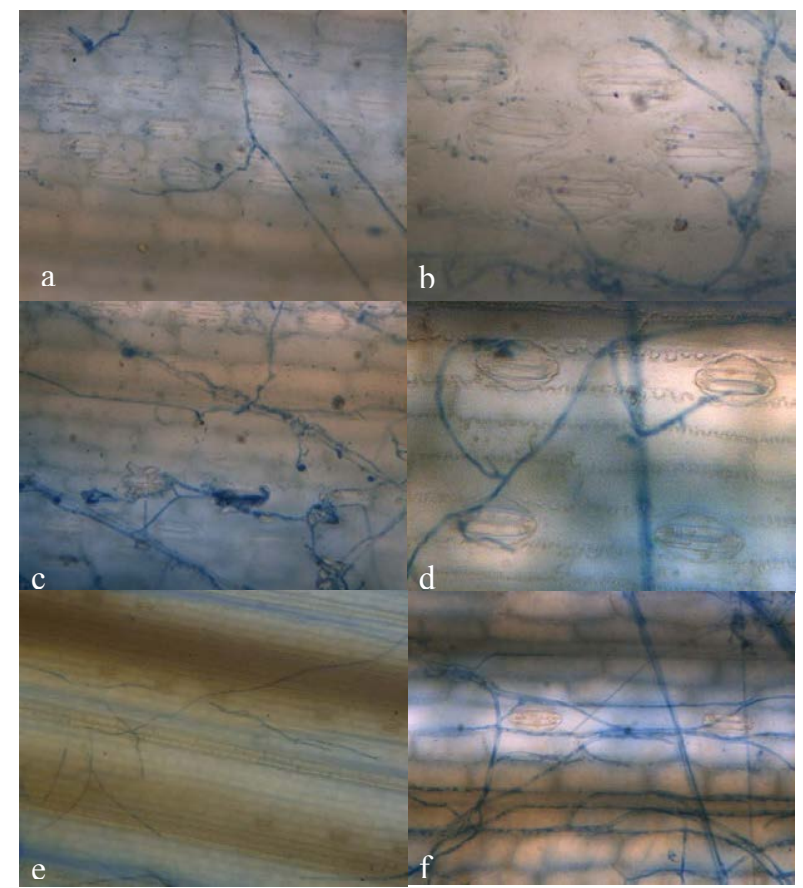

Figure 2: The performance of Sclerotium rolfsii isolate SC64 on surface of Cyperus difformis $(\mathrm{a} \sim \mathrm{d}, 40 \times)$ and non-susceptible Cyperus species. (e C. rotundus L., $20 \times$; $\mathrm{f}$. iria L.,40×).
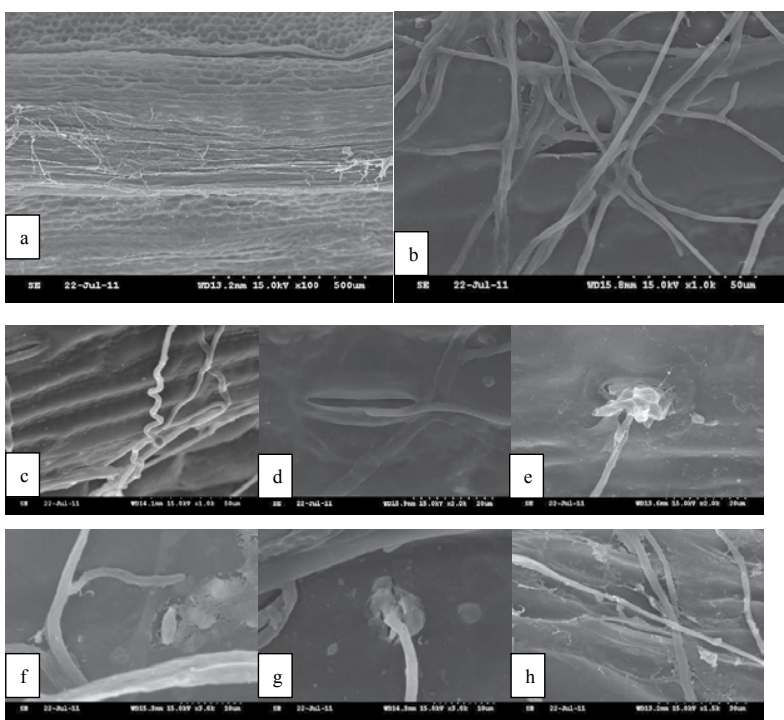

Figure 3: Development of Sclerotium rolfsii isolate SC64 on stem of Cyperus difformis observed with scanning electron microscopy (a) Hyphae of $S$. rolfsii SC64 on the leaf surface which formed a dense hyphal network, 100x; (b) Branching hyphae of S. rolfsii SC64, 1000x; (c, d, e) Wavelike hyphae spreading on the leaf surface, secreting mucilage and entered into the host tissues through the stromata, 1000x; $2000 \times$ and 2000x, respectively; (f, g h) Mucilage covering hyphal tips and ramifying hyphea entered into the host tissues through crevasses on the stem surface, 3000x; $3000 \times$ and 1500x, respectively.
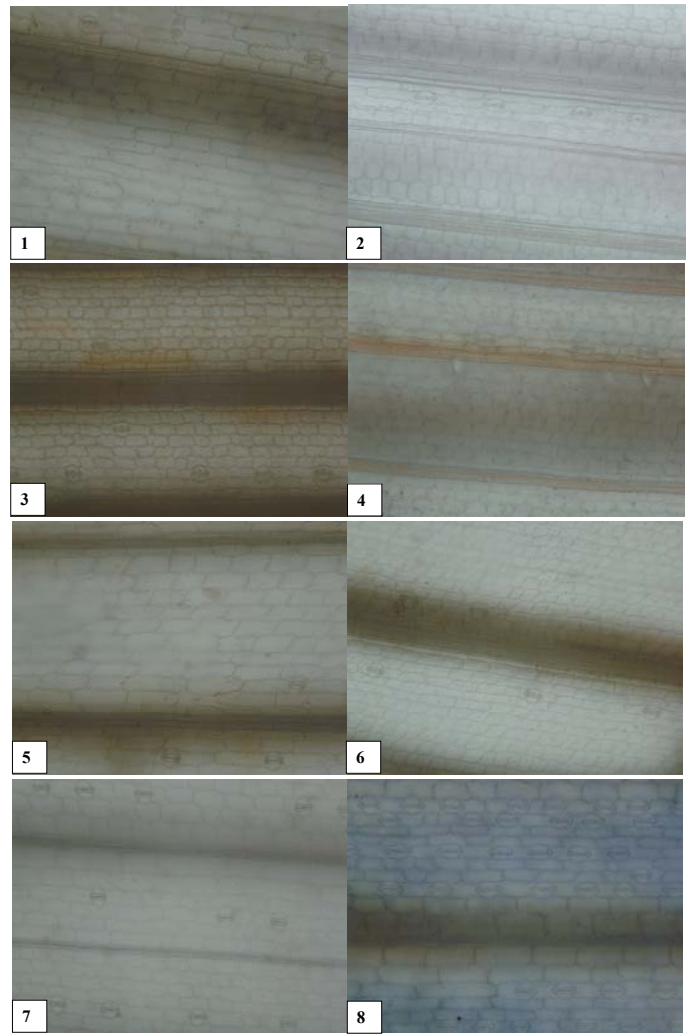

Figure 4: Microphotographs of basal stem leaf abaxial epidermis under $L M$ (20x, dark lines in the pictures were leaf veins). 1. C amuricus Maxim.; 2. C. compressus L.; 3. C. cuspidatus H.B.K.; 4. C. glomeratus L.; 5. C. iria L.; 6. C. rotundus L.; 7. C. difformis L.; 8. C. difformis L. (upper leaves). 
Citation: Tang W, Kuang J, Qiang S (2015) The Pathogenicity of Sclerotium rolfsii on Cyperus difformis and its Potential Host Specificity among the Genus Cyperus. J Plant Pathol Microbiol S3: 002. doi:10.4172/2157-7471.S3-002

Page 4 of 6

\begin{tabular}{|c|c|c|c|c|c|c|c|c|}
\hline Species & $\begin{array}{c}\text { Shape of long-cells between } \\
\text { veins }\end{array}$ & Short cells & $\begin{array}{c}\text { Place that stomata } \\
\text { present }\end{array}$ & $\begin{array}{l}\text { Number of } \\
\text { stomata } \\
\text { under } 20 \times \\
\text { microscopic } \\
\text { ocular }\end{array}$ & $\begin{array}{l}\text { Length/width } \\
\text { of stomata) }\end{array}$ & $\begin{array}{c}\text { Shape of } \\
\text { subsidiary cells }\end{array}$ & $\begin{array}{l}\text { Place that } \\
\text { papilleas } \\
\text { present }\end{array}$ & Shape of guard cells \\
\hline $\begin{array}{l}\text { C. amuricus } \\
\text { Maxim. }\end{array}$ & Long-tubular, simuous & Absent & $\begin{array}{l}\text { Close to the leaf veins } \\
\text { ( } 2 \text { or } 3 \text { rows of cells } \\
\text { from the leaf veins) }\end{array}$ & 3 & 1.27 & Dome-shaped & Over the veins & $\begin{array}{l}\text { Both sides not } \\
\text { obviously thicker }\end{array}$ \\
\hline $\begin{array}{l}\text { C. cuspidatus } \\
\text { H.B.K. }\end{array}$ & Long-tubular, simuous & Absent & $\begin{array}{l}\text { Close to the leaf veins } \\
\text { ( } 2 \text { or } 3 \text { rows of cells } \\
\text { from the leaf veins) }\end{array}$ & 7 & 1.06 & Dome-shaped & Over the veins & $\begin{array}{c}\text { Both sides obviously } \\
\text { thicker }\end{array}$ \\
\hline C. rotundus $\mathrm{L}$. & Long-tubular, simuous & Absent & $\begin{array}{l}\text { Close to the leaf veins } \\
\text { ( } 2 \text { or } 3 \text { rows of cells } \\
\text { from the leaf veins) }\end{array}$ & 4 & 1.33 & Dome-shaped & Over the veins & $\begin{array}{c}\text { Both sides obviously } \\
\text { thicker }\end{array}$ \\
\hline C. glomeratus L. & $\begin{array}{l}\text { Short-tubular to long-tubular, } \\
\text { simuous }\end{array}$ & Absent & $\begin{array}{c}\text { Close to the leaf veins } \\
\text { (2 rows of cells from } \\
\text { the leaf veins) }\end{array}$ & 5 & 1.56 & Dome-shaped & Over the veins & $\begin{array}{l}\text { Both sides not } \\
\text { obviously thicker }\end{array}$ \\
\hline C. iria L. & $\begin{array}{l}\text { Short-tubular to long-tubular, } \\
\text { simuous }\end{array}$ & Absent & $\begin{array}{l}\text { Close to the leaf veins } \\
\text { ( } 2 \text { or } 3 \text { rows of cells } \\
\text { from the leaf veins) }\end{array}$ & 2 & 1.06 & Dome-shaped & Over the veins & $\begin{array}{l}\text { Both sides not } \\
\text { obviously thicker }\end{array}$ \\
\hline C. compressus L. & $\begin{array}{l}\text { Short-tubular, rarely sub- } \\
\text { terragonal, deeply simuous }\end{array}$ & Absent & $\begin{array}{c}\text { Close to the leaf veins } \\
\text { ( } 2 \text { rows of cells from } \\
\text { the leaf veins) }\end{array}$ & 5 & 1.66 & $\begin{array}{l}\text { Dome-shaped } \\
\text { to triangular }\end{array}$ & Over the veins & $\begin{array}{c}\text { Both sides obviously } \\
\text { thicker }\end{array}$ \\
\hline C. difformis $\mathrm{L}$. & $\begin{array}{l}\text { Short-tubular, rarely sub- } \\
\text { terragonal, deeply simuous }\end{array}$ & Absent & $\begin{array}{c}\text { Between the leaf veins } \\
\text { ( } 3 \text { or } 4 \text { rows of cells } \\
\text { from the leaf veins) }\end{array}$ & 7 & 0.99 & $\begin{array}{l}\text { Dome-shaped } \\
\text { to triangular }\end{array}$ & Over the veins & $\begin{array}{c}\text { Both sides obviously } \\
\text { thicker }\end{array}$ \\
\hline
\end{tabular}

Table 3: The comparison of the main micro-morphology characters of leaf abaxial epidermis of 7 species of Cyperus.

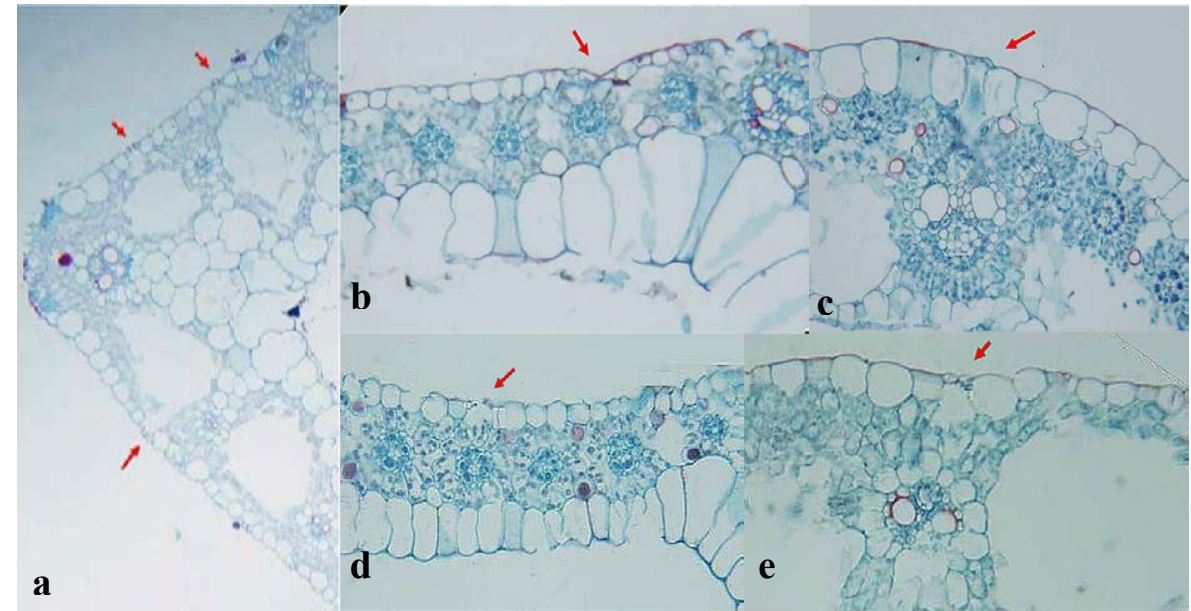

Figure 5: The transverse section of some Cyperus species (arrow shows the place of stomata, 40x) (a C. difformis L.; b C. cuspidatus H.B.K.; c C. iria L.; d C. glomeratus L.; e C. amuricus Maxim.).

characters, e.g. the shape of long-cells long-tubular or short-tubular, rarely sub-tetragonal, the margin of cell walls sinuous or deeply sinuous; short cells absent; stomatal subsidiary cells triangular, domeshaped to triangular, tall dome-shaped and dome-shaped; papillaes present over the veins (Figure 4). However, the presence, shape, and distribution of stromata in the epidermal surface were different from other six Cyperus species. The stomata of $C$. difformis were always present between the leaf veins ( 3 or 4 rows of cells from the leaf veins). The density of stromata was relatively higher and the length/width of stomata was relatively lower than other six Cyperus species. We propose that the micro-morphological characteristics of stromata may play an important role in the fungal infectivity.

The comparison of transverse section of Cyperus species: The differences of stromata characteristics between C. difformis and the non-susceptible Cyperus species were visually apparent in the examination of basal leaf cross-sections (Figure 5). Vascular bundle was always present underneath the leaf veins. The stromata of the non-susceptible Cyperus species were always close to the leaf veins, so under the stromata were mesophyll cell, bundle sheath cell and vascular bundle. However, the case was different in C. difformis, where the stromata presented in the middle of vascular bundles and below the stromata was air space. From this point of view, the structure of $C$. difformis was more beneficial for fungus infection.

\section{Discussion}

Sclerotium rolfsii is a polyphagous pathogen in the world and new record of host species are reported continually, which includes some monocotyledonous plants e.g. Poa annua L. [11], garlic (Allium sativum) [12]; Asiatic dayflower (Commelina communis L.) [13]. Our experiment on the stem rot of $C$. difformis caused by $S$. rolfsii contributes one more new host specie for this fungus. Further studies on the fungus have shown that it is an effective agent of biological control of the weed in dry direct-seeded rice [10]. 
Citation: Tang W, Kuang J, Qiang S (2015) The Pathogenicity of Sclerotium rolfsii on Cyperus difformis and its Potential Host Specificity among the Genus Cyperus. J Plant Pathol Microbiol S3: 002. doi:10.4172/2157-7471.S3-002

In the host specificity test of our study the primary nutrient sources of $S$. rolfsii was mycelium grown from PDB medium. Hyphae growing from the PDB suspension extended and ramified on the stem surfaces. However, there is substantial hyphae growth and extension difference under the light microscopy. Only the atomata of $C$. difformis were adhered by ramified hyphae of $S$. rolfsii. The pathogen directly penetrates the host surface via stomata. Therefore, stomata play an important role for $S$. rolfsii infection of $C$. difformis. However, stomatapenetrating pathogens need appropriate cues to locate stomata pores [14]. The development of wavelike hyphae may be assumed to increase the adhesion of the pathogen to the host surface in order to effectively reach the stomata. Leaf veins located close to stomata of the resistant Cyperus species might a natural fence, making a false angle for the eruptive hyphae.

Infection cushions are produced by many plant pathogenic fungi (e.g. Sclerotinia sclerotiorum; Rhizoctonia solani) and these structures were reported to facilitate infection of the host [15-17]. Previous studies have reported the occurrence or presumed functions of hyphal aggregates which were formed during infection of host tissue by $S$. rolfsii [5,18]. Infection was also reported to occur from appressoria produced by germinating basidiospores of the teleomorph of $S$. rolfsii [19]. In this study, neither multicellular compound appressoria (infection cushions) nor flattened hyphae was observed on the host surface. After penetration into mesophyll via stomata, the host tissue turned yellowish-brown soft and the cuticle became disintegrated. Then hyphae entered into the host tissue through the rifts. S. rolfsii produce extracellular enzymes including pectin methyleasterase [7], cutinase [20], phosphatidase [21], arabanase [22], galatanase, mannanase, xylanse [23], oxalic acid and polygalacturonase [24]. It is assumed that tissue death in advance of mycelial growth during infection of $C$. difformis by $S$. rolfsii.

Plant defense against pathogen attack is complex, with many local and systemic aspects [25]. The internal anatomy and surface features of the leaves often determine plant resistance to biotrophic pathogen infection [26]. Among such characters, aspects of stromata, cuticle and trichome morphology can influence disease resistance [27]. We compared the transverse section of $C$. difformis and some other resistant Cyperus species and found that the variation of stomata distribution was in relation to the stem anatomy. The air chamber underneath the stomata of $C$. difformis provides the weakest mechanical obstruction to fungal penetration, while the vascular bundle underneath the stomata of resistant Cyperus may be a natural barrier.

In rust fungi, the emerging germ tubes adhere first to the leaf surface; subsequently, they grow and encounter stomata through directional growth [28], which in turn triggers appressorium formation [29]. Directional growth of the germ tube and formation of appressorium are controlled by the stimuli originating from the host [30]. It seems that, for the first time, an alternative 'avoidance' or prepenetration mechanism is apparent in Cyperus - S. rolfsii interaction, which operates after the contact of parasite on the host epidermal cell $[31,32]$. However, we failed to observe the extension of hyphae inter- and intracellularly. More details of the infection process, the effect of mechanical obstacles of epidermis (eg. waxy deposition) and the mechanism of directional growth of hyphae all require further investigation.

\section{Acknowledgement}

The authors thank Miss Yufang Chen and Huizhi Lin for their excellent technical assistance. Financial support was provided by the $863 \mathrm{Hi}$-tech Research
Project (2011AA10A206), Science \& Technology Pillar Program of Jiangsu Province (BE2011353), Ph.D. Programs Foundation of Ministry of Education of China (20090097110018) and the 111 project.

\section{References}

1. Punja ZK (1985) The biology, ecology, and control of Sclerotium rolfsii. Annual Review of Phytopathology 23: 97-127.

2. Hall R (1991) Compendium of Bean Diseases. The American Phytopathology Society, St Paul. M.N. USA, Pp 115.

3. Agrios GN (2004) Plant Pathology. (5thedn) San Diego, CA: Academic Press.

4. Hollowell JE, Shew BB (2001) Yellow Nutsedge (Cyperus esculentus L.) As a host of Sclerotinia minor. Plant Disease 85: 562.

5. Higgins BB (1927) Physiology and parasitism of Sclerotium rolfsii Sacc. Phytopathology 17: 417-448.

6. Milthorpe FL (1941) Studies on Corticium rolfsii (Sacc.) Curzi (Sclerotium rolfsii Sacc.). I. Cultural characters and perfect stage. II. Mechanism of parasitism. Proceedings of the Linnean Society of New South Wales 66: 65-75.

7. Bateman DF, Beer SV (1965) Simultaneous production and synergistic action of oxalic acid and polygalacturonase during pathogenesis by Sclerotium rolfsii. Phytopathology 55: 204-211.

8. Gubitz GM, Hayn M, Sommerauer M, Steiner W (1996) Mannan degrading enzymes from Sclerotium rolfsii: Characteristics and synergism of two endo $\mathrm{N}$-mannosidase. Bioresource Technology 58: 127-135

9. Tang W, Zhu YZ, He HQ, Qiang S (2010) First report of southern blight on Canadian goldenrod (Solidago canadensis) caused by Sclerotium rolfsii in China. Plant Disease 94: 1172.

10. Tang W, Zhu YZ, He HQ, Qiang S, Auld BA (2011) Field evaluation of Sclerotium rolfsii, a biological control agent for broadleaf weeds in dry directseeded rice. Crop Protection 30, 1315-1320.

11. Kane KT (1992) First Report of Sclerotium rolfsii Infection of Poa annua in Illinois. Plant Disease 76: 538.

12. Kwon JH (2010) Stem Rot of Garlic (Allium sativum) Caused by Sclerotium rolfsii. Mycobiology 38: 156-158.

13. Choi O, Kwon JH, Min Y, Kim J (2011) First Report of Stem Rot on Asiatic Dayflower (Commelina communis L.) Caused by Sclerotium rolfsii in Korea. Mycobiology 39: 57-58.

14. O'Connell RJ, Panstruga $R$ (2006) Tête à tête inside a plant cell: establishing compatibility between plants and biotrophic fungi and oomycetes. New Phytol 171: 699-718.

15. Hofman TW, Jongebloed PHJ (1988) Infection process of Rhizoctonia solani on Solanum tuberosum and effects of granular nematicides. Netherlands Journal of Plant Pathology 94: 243-252.

16. Jamaux I, Gelie B, Lamarque C (1995) Early stages of infection of rapeseed petals and leaves by Sclerotinia sclerotiorum revealed by scanning electron microscopy. Plant Pathology 44: 22-30.

17. Zheng AP, Wang YR (2011) The research of infection process and biological characteristics of Rhizoctonia solani AG-1 IB on soybean. Journal of Yeast and Fungal Research 2: 93-98.

18. Smith VL, Punja ZK, Jenkins SF (1986) A histological study of infection of host tissue by Sclerotium rolfsii. Phytopathology 76: 755-759.

19. Punja ZK, Grogan RG (1983) Germination and infection by basidiospores of Athelia (Sclerotium) rolfsii. Plant Disease 67: 875-878.

20. Baker CJ, Bateman DF (1978) Cutin degradation by plant pathogenic fungi. Phytopathology 68: 1577-1584

21. Kaveriappa KM (1979) Mutual aversion in brinjal isolates of Sclerotium rolfsii. Indian Phytopathology 32: 475-477.

22. Cole AL, Bateman DF (1969) Arabanase production by Selerotium rolfsii and its role in tissue maceration. Phytopathology 59: 1750-1753.

23. Sadana JC, Shewale JG, Deshpande MV (1980) High Cellobiase and Xylanase Production by Sclerotium rolfsii UV-8 Mutant in Submerged Culture. App Environ Microbiol 39: 935-936.

24. Bateman DF (1972) The polygalacturonase complex produced by Sclerotium rolfsii. Physiological Plant Pathology 2: 175-184 
Citation: Tang W, Kuang J, Qiang S (2015) The Pathogenicity of Sclerotium rolfsii on Cyperus difformis and its Potential Host Specificity among the Genus Cyperus. J Plant Pathol Microbiol S3: 002. doi:10.4172/2157-7471.S3-002

Page 6 of 6

25. Felle HH, Herrmann A, Hanstein S, Hückelhoven R, Kogel KH (2004) Apoplastic ph signaling in barley leaves attacked by the powdery mildew fungus Blumeria graminis f. Sp. Hordei. Mol Plant Microbe Interact 17: 118-123.

26. Smith PH, Foster EM, Boyd LA, Brown JKM (1996) The early development of Erysiphe pisi on Pisum sativum L. Plant Pathology 45: 302-309.

27. Niks RE, Rubiales D (2002) Potentially durable resistance mechanisms in plants to specialized fungal pathogens. Euphytica 124: 216-216.

28. Wynn WK, Staples RC (1981) Tropism of fungi in host recognition. In: Staples RC, Toenilsen GA, eds. Plant disease control: resistance and susceptibility. New York: John Wiley 45-69.
29. Anker C, Niks RE (2001) Prehaustorial resistance to the wheat leaf rust fungus, Puccinia triticina, in Triticum monococcum (s.s). Euphytica 117: 209-215.

30. Hoch HC, Staples RC (1987) Structural and chemical changes among the rust fungi during appressorium development. Annual Review of Phytopathology 25 231-247.

31. Rubiales D, Niks RE (1992) Low appressorium formation by rust fungi on Hordeum chilense leaves. Phytopathology 82: 1007-1012.

32. Vaz Patto MC, Fernandez-Aparicio M, Moral A, Rubiales D (2009) Pre- and post-haustorial resistance to rust in Lathyrus cicera L. Euphytica 165: 27-34. 